\title{
Motivation Perspectives on Opening up Municipality Data: Does Municipality Size Matter?
}

\author{
Anneke Zuiderwijk ${ }^{1, *}$, Cécile Volten ${ }^{1}$, Maarten Kroesen ${ }^{1}$ and Mark Gill ${ }^{2}$ (I) \\ 1 Faculty of Technology, Policy and Management, Delft University of Technology, \\ 2628 BX Delft, The Netherlands; C.J.Volten@student.tudelft.nl (C.V.); M.Kroesen@tudelft.nl (M.K.) \\ 2 University of British Columbia Okanagan, Kelowna, BC V1V 1V7, Canada; mark.richard.gill@gmail.com \\ * Correspondence: a.m.g.zuiderwijk-vaneijk@tudelft.nl; Tel.: +31-15-27-85828
}

Received: 2 October 2018; Accepted: 18 October 2018; Published: 25 October 2018

\begin{abstract}
National governments often expect municipalities to develop toward open cities and be equally motivated to open up municipal data, yet municipalities have different characteristics influencing their motivations. This paper aims to reveal how municipality size influences municipalities' motivation perspectives on opening up municipality data. To this end, Q-methodology is used, which is a method that is suited to objectify people's frames of mind on a particular topic. By applying this method to 37 municipalities in the Netherlands, we elicited the motivation perspectives of three main groups of municipalities: (1) advocating municipalities, (2) careful municipalities, and (3) conservative municipalities. We found that advocating municipalities are mainly large-sized municipalities ( $>65,000$ inhabitants) and a few small-sized municipalities $(<35,000$ inhabitants). Careful municipalities concern municipalities of all sizes (small, medium, and large). The conservative municipality perspective is more common among smaller-sized municipalities. Our findings do not support the statement "the smaller the municipality, the less motivated it is to open up its data". However, the type and amount of municipality resources do influence motivations to share data or not. We provide recommendations for how open data policy makers on the national level need to support the three groups of municipalities and municipalities of different sizes in different ways to stimulate the provision of municipal data to the public as much as possible. Moreover, if national governments can identify which municipalities adhere to which motivation perspective, they can then develop more targeted open data policies that meet the requirements of the municipalities that adhere to each perspective. This should result in more open data value creation.
\end{abstract}

Keywords: open data; municipality; size; motivation; open government data; policy; perspective; open cities; Q-methodology

\section{Introduction}

Open cities are cities that accommodate the differences between citizens, incorporate unpredictable changes, and foster adaptation [1,2]. In an open city, residents contribute to its efficiency, safety, and sociability by virtue of their own agency [3]. Open cities are solution-oriented and demand-driven. They stimulate economic growth, innovation, and cultural emancipation through the interaction of residents from a variety of backgrounds [4]. In contrast, closed cities enforce more control in interactions with citizens, have more linearity, and work more similar to a "machine" [5]. Open cities stimulate innovation and non-linearity, and leave space for improvements and interaction [5]. Open data can be used as a way to stimulate the openness of cities and make them smarter, more innovative, and more sustainable [6-9]. Data collected by cities can be opened up and used to create added value and develop innovative services [10]. Hence, open data is becoming an important topic on the agendas of many 
municipalities. Municipalities open up municipal data in order to attain a large range of economic, social, and political benefits [11], such as for example to become more transparent, accountable, and engaging [9]. Opening up data at the local level can lead to proactive civic engagement [12]. Municipal data that is particularly considered socially and economically valuable includes data concerning events, health services, monuments, addresses, public space, sport facilities, garbage collection, subsidies, shopping areas, education, and work on the roads [13]. However, as civic, non-governmental organisations (NGOs), and commercial users of municipal data use data in innovative ways, they continue to redefine what is considered valuable data.

National governments often expect municipalities to equally take part in the open data movement by opening up data concerning the above-mentioned topics. However, municipalities may be motivated differently to open up their data, and may follow different paths in the implementation of open data initiatives [14]. Local governments are struggling more with the opening of their data than national governments, since they have less resources and capabilities [15]. Previous research has suggested that differences in motivations may be correlated with scale-related characteristics of municipalities $[16,17]$. For example, the type and amount of governmental resources that are available to larger-sized municipalities may be different from those of smaller-sized municipalities [17], making it easier or more difficult to open up data. Moreover, the population and business composition of larger municipalities may be different than those of smaller municipalities, resulting in different data needs and resulting in the publication of different types of data by the municipality. Furthermore, the type of data that is being collected may be different for smaller-sized municipalities [17], since the services and facilities provided by smaller-sized municipalities may be different.

Research on open municipal data has mainly concentrated on the particular case studies of specific municipalities without considering the influence of municipality size, e.g., $[12,14,18-20]$. There is only limited research into open data policies that accounts for the differences in municipality size $[16,17,21]$. Previous research that has focused on the motivation perspectives of municipalities in relation to municipality size has concentrated mainly on Western Canada and the United States, and has not been examined in other countries. For instance, Gill [16] focused on how the potential benefits of open data are conceived differently by municipality representatives depending on the municipality size in Western Canada; Gill and Corbett [17] focused on testing the connection between the efficacy of open data portals and the population size of municipalities in Canada; Gill, Corbett, and Sieber [21] examined how the size of municipalities influences how open data is developing at municipalities of different sizes in Western Canada. In addition, Thorsby et al. [22] looked at the impact of the population size of American cities and their level of resources on the number of datasets made available, and, Pinto et al. [23] categorized the datasets of open data portals of large American cities.

This paper aims to reveal how municipality size influences municipalities' motivation perspectives on opening up municipality data. If national governments can identify which municipalities adhere to which motivation perspective, they can then develop more targeted open data policies that meet the requirements of the municipalities adhering to each perspective, which should result in the realization of more benefits and in more open data value creation. Applying Q-methodology, we elicit and categorize the motivation perspectives for opening up data by municipalities in the Netherlands, and formulate recommendations for municipal open data policy-making. In the following section, we first discuss the relevant literature on motivations for opening up municipal data, potential size-related differences in open data policies, and the landscape of open municipal data in the Netherlands. We then outline the approach that we used in this study, and provide an overview of the main perspectives of municipalities on opening up municipal data and their differences and similarities. Finally, we set out our recommendations for national governments on how to account for motivation perspectives and municipality size when developing future open data policies, and we discuss our conclusions. 


\section{Research Background}

In this section, we discuss the motivations for opening up municipal data (Section 2.1), the potential size-related differences in open data policies (Section 2.2), and provide an overview of the landscape of open municipal data in the Netherlands (Section 2.3).

\subsection{Motivations for Opening Up Municipal Data}

Cities are an essential element of the open data publication chain [24]. The maturity of open data implementation in cities differs [24]. Moreover, different approaches to start these initiatives have been used. Some cities, such as Dublin, Florence, Lisbon, and Helsinki started their open data journey adopting a top-down approach, meaning that they were initiated by the political leadership of the city [24]. In other cities, such as Ghent, a bottom-up approach is used, which started due to the initiative of local communities, the university, students, and Open Knowledge Belgium [24].

Previous research found that municipalities participate in open data initiatives for various reasons. The two main reasons found by Lassinantti, Bergvall-Kåreborn, and Ståhlbröst [14] are (1) to create a platform for techno-economic growth, and (2) to co-create societal growth. The techno-economic growth is often linked to the term "smart city", and relates to reusing data for economic purposes and developing data driven-services that should make the life of residents easier [9]. Social growth is often used in the context of "open cities", and relates more to the concepts of participation, engagement, accountability, and openness (idem). In practice, municipalities that open up their data often do this for diverging reasons. For instance, the municipality of Amsterdam opens up data for reasons of transparency (i.e., citizens need to know what the municipality does), releasing social and commercial value (i.e., open data as a resource for social and commercial activities), enabling participatory governance (i.e., informing citizens and involving them in decision-making), and increasing efficiency (i.e., making the data also internally available for all of the employees in the municipality) [25]. The City Data Strategy of London focuses on an outcome-aligned economy (i.e., a city data economy that is less fragmented and complex for data creators), a sharing market culture (i.e., both in the public and private sector), a coordinated data infrastructure (i.e., valuable interoperable integrated services) and non-technical elements (i.e., business models, value networks, feedback loops) [26]. Other examples concern the "City of People" strategy of Ghent, aiming for improving the well-being of its inhabitants, and the Open Vilnius strategy, aiming at, among others, saving money, helping inhabitants adopt more sophisticated solutions, and sharing [24].

\subsection{Potential Size-Related Differences in Open Data Policies}

Previous research shows that municipalities cannot keep up with the pace of opening up data by larger open data initiatives, such as those at the provincial or national level [14]. This suggests that the size of open data initiatives at the level of municipalities may also matter. Gill [16] was among the first to study the effect of municipality size on open data initiatives, and found that the potential benefits of open data are conceived differently by municipality representatives depending on the municipality size. He found that the representatives of smaller municipalities believed that smaller municipalities were less likely to realize potential open data benefits compared to larger municipalities, since they felt that they had fewer resources, and that their communities would be less interested in open data (idem).

There may be several reasons for the differences in open the data policies of smaller-sized municipalities compared to mid-sized or larger-sized municipalities. For example, the type and amount of governmental resources may be different [17]. Many municipalities lack the financial resources to invest even in basic information technology (IT) services [27]. Large municipalities usually have more money and personnel to ensure that the necessary human resources, information, data resources, and information technology (IT) resources are in place. Human resources include computer skills, the ability to interpret open data, the ability to select the right open data tools, and the management of the stakeholder network [28]. Data and information resources refer to databases with 
open datasets and open data-related products and services (idem). IT resources include, among others, available hardware and software systems, IT applications, IT knowledge, and raw IT spending [29]. Using these resources allows larger municipalities to create an open data policy and develop a specific strategy for open data sharing, which smaller-sized municipalities may be lacking.

Another size-related factor potentially affecting open data policies concerns the population and the communities that are interested in open data [17]. The population and business composition of larger municipalities may be different from those of smaller municipalities, resulting in different data needs and resulting in the publication of different types of data by the municipality. For instance, information, communication and technology (ICT)-related companies may not be located in smaller-sized municipalities. Those are the companies that are expected to make the most use of open data economically, typically by creating products or services that use these data. In municipalities that consist of communities interested in open municipal data, there may be a stronger push to open up various types of municipal data.

Furthermore, the type of data being collected may be different for smaller-sized municipalities [17], since the services and facilities provided by smaller-sized municipalities may be different. For example, the services of smaller-sized municipalities may be less digitalized; there may be less events and locations that are interesting to share municipal datasets about (e.g., less or no festivals, shopping areas, and other places of entertainment).

\subsection{The Landscape of Open Municipal Data in the Netherlands}

At the beginning of 2017, 42 Dutch municipalities (11\% of the total at that time) disclosed one or more datasets as open data [13]. As open data continues to develop at government organizations of different sizes, it is important to also understand how it is developing in smaller municipalities and districts, because of the potential differences associated with size (e.g., population size; governmental resources; citizen, organization, and business interest in open data; and types of data collected and published by governments).

In the Netherlands, the scientific research on open data in municipalities has almost exclusively studied large open data municipalities, such as Amsterdam [30] and Rotterdam [31]. Although many Dutch municipalities have published reports about their individual open data strategies, we were only able to locate one report in which open data strategies concerning multiple Dutch municipalities are examined and compared [13]. The research by De Jager-de Lange [13] showed that large Dutch municipalities open up data more often than small Dutch municipalities. Almost half of all of the opened datasets are provided by large municipalities. Moreover, in the Netherlands, municipal open datasets are geographically fragmented [13]. The use of data from Dutch municipalities is currently hindered because the datasets are not findable, are different in form, format, and content, and opened up municipal datasets do not cover multiple municipalities [13]. The limited amount of available research concerning Dutch municipalities and their perspectives on participating in open data initiatives motivates us to study Dutch municipalities in particular.

\section{Research Design: Q-Methodology}

\subsection{The Q-Method Procedure}

The Q-method is a method that combines principles from qualitative research (e.g., the principle of contextuality [32], see below) with quantitative research methods (factor analysis). The research method is ideally suited to reveal and understand the variation in subjective perspectives on a particular topic [33]. It is suitable for studies that search for advancing theory development [34,35], and where many subjective factors impact behaviour [36], as is the case in this study. As such, it is well-suited to achieve our objective of revealing municipalities' motivation perspectives on opening up municipality data. This method has already been successfully applied in the area of psychology [35], information systems [37], and other areas. Given the many factors influencing the motivations for opening up and 
using municipal data, Q-methodology is an essential step that is needed before large-scale testing can take place to assess the statistical occurrence of motivations in a certain population (as also done by Benlian, et al. [37]). The procedure of the Q-method consists of four steps [38].

- The first step consists of defining the concourse. The concourse includes all of the statements of opinion regarding a particular topic, which may be expressed in text or verbally [32]. Typically, the concourse consists of too many statements for the Q-sorting task (the next step), and therefore needs to be reduced to a smaller size, while still being representative of the complete variety of opinions. This selection is termed the Q-set, and usually contains around 30-60 statements [39].

- In the next step, a sample of strategically selected participants (based on predefined criteria) will sort the Q-set in a rank-ordering task. In this respect, no complete ordering is required, but a partial one, using a forced distribution, is sufficient [32]. The scale that is used to guide the ordering process should also be defined. Typically, respondents are asked to indicate their level of (dis)agreement with each statement. The rank-orderings thus obtained are referred to as Q-sorts. They can be interpreted as different viewpoints regarding the subject under study.

- In the third step, shared viewpoints are identified by subjecting the Q-sorts to a (by-person) factor analysis [32]. The factor analysis will ensure that participants with similar Q-sorts (viewpoints) are clustered together, loading on the same factor. After extraction, a rotation method is usually applied to obtain a simple structure. Based on the resulting factor loading matrix, common viewpoints can be revealed by computing the standardized factor scores. These reflect how individuals who load on a particular factor (on average) score on the statements in the Q-set, thus representing a shared viewpoint.

- In the final step, the factor scores form the basis for the interpretation of each viewpoint. Here, each score on a statement is interpreted in the context of all of the other scores (the principle of contextuality). The challenge of the interpretation lies in developing a narrative for each factor that can account for all of the factor scores. Usually, the interpretation is supported by the comments made by participants.

The data that we collected through these steps is publicly available at the Data Repository of the 4TU.Centre for Research Data (Volten, C.J. (Cécile) (2018) Motivation perspectives Open Data. TU Delft. Dataset. https:/ / doi.org/10.4121/uuid:a8c6ac03-2b2f-4737-bf1e-0603dfd4baa4).

\subsection{Q-Set Creation}

The concourse was developed by collecting statements from sources discussing the advantages and disadvantages of open data provision by municipalities. In order to capture all of the possible motivations/barriers, different types of sources were considered, namely scientific literature, news articles, policy documents, and an online forum for employees of Dutch municipalities. In the end, the concourse consisted of 103 statements (listed in Appendix A). To select the statements for the Q-set, the collected statements were first clustered using categories identified by Janssen et al. [40]. The advantages of opening up data are categorized into political and social benefits and economic benefits. The obstacles that are seen when opening data are categorized into institutional obstacles, problems with (re)use, legislation obstacles, and open data requirements. Below, we discuss which particular statements from the concourse were selected to form the Q-set. In the end, 39 statements were selected. The following paragraphs summarize the 39 Q-set statements broken into topics.

\subsubsection{Political and Social Benefits}

From the sources that discussed political and social benefits we conclude that for municipalities opening up, data is often associated with the importance of being open and transparent (No. 6). It is stated that when a municipality is open, the democratic legitimacy will improve [41] (No. 9). To fully reach this goal, it is important for residents to be able to monitor what the municipality is doing [42] (No. 1). In this way, the data that is gathered by a municipality can be worth more when opened 
up [43,44] (No. 3). This requires that municipalities should not fear the opening of data due to potential negative consequences, such as using the opened data for espionage.

\subsubsection{Economic Benefits}

The studied sources also show that opening up data can lead to economic advantages. In order to create economic value, it is important for the economy of a country that companies have access to municipality data [45] (No. 11). It should thus be allowed for data to be used for commercial purposes. The open data can be a source for innovation [46,47] (No. 14), and is thus of meaning for both residents and companies [47] (No. 13).

\subsubsection{Institutional Obstacles}

Municipal motivation perspectives are also focused on motivations for not opening up data [40]. An obstructing factor could be the culture of the organization [48,49]. In the municipal culture, there might be a lack of data awareness, and hence the opening of data is not part of the daily activities [50-52]. Moreover, municipal employees might not want to spend additional effort in opening up municipality data [50] (No. 23), or they are not aware of open data at all [51] (No.15).

\subsubsection{Problems with (Re)Use}

The municipality should be responsible for stimulating the reuse of opened data [48,53] (No. 24), but the question is whether municipalities really want to do this [54]. Moreover, the question is if the municipality has to open up all of the possible data or only several specific (e.g., high-value) datasets [55] (No. 30). The opening of data might lead to negative consequences (e.g., financial consequences) for the municipality [56] (No. 29), which might be prevented by only providing data for payment [46] (No. 25). However, this does not adhere to the open data principles. Another problem that can be encountered is that the municipality does not have enough means to open the data [57] (No. 27).

\subsubsection{Legislation Obstacles}

Legislation could provide possible barriers whilst opening up data [56] (No. 34). The opening of data could lead to privacy risks if the ones that are responsible do not properly anonymize the dataset $[58,59]$. The legislation that is already in place should prevent this from happening [50] (No. 33), but it can impede with the opening of data [56] (No. 34). Another difficulty with the legislation is the discussion about ownership $[60,61]$. Does the municipality own the data, or is the data the collective property of the residents? (No. 32).

\subsubsection{Open Data Requirements}

Whilst opening data, several agreements should be made by the government about standard ways to open up data. These need to increase inhabitants' understanding of opened datasets $[48,62,63]$ (No. 39). Furthermore, the datasets have to be veracious in order to improve inhabitants' trust in and use of the data [59] (No. 35). This might be done by adding metadata [62] (No. 37) or opening up data that is as raw and complete as possible [64] (No. 36).

\subsection{Respondent Selection}

The aim of any Q-method study is not to generalize results to a population of people, but rather to be representative for the richness of the opinion space related to the topic under study. Consequently, respondents are not randomly selected from a sampling frame, but strategically based on characteristics that, beforehand, are believed to affect respondents' viewpoints (based on existing literature and other information sources). By deliberately ensuring sufficient variation of these characteristics, the underlying intent is to reveal all of the viewpoints that exist in practice. 
In this research, the motivation perspectives of municipal officials are researched. In the study of Gill, Corbett, and Sieber [21] it was found that the size of municipalities matters when looking at open data perspectives. The size of the municipality is operationalized here as the number of inhabitants. Three categories are considered:

- larger-sized municipalities: more than 65,000 inhabitants;

- mid-sized municipalities: more than 35,000 but less than 65,000 inhabitants;

- $\quad$ smaller-sized municipalities: less than 35,000 inhabitants.

Assuming that municipal ICT officials or officials working with open data would best reflect the municipality's viewpoint on open data, these people were invited to take part in the study. Given the scope of the research, only Dutch municipalities were included. In the end, 37 municipality officials participated in the study. Table 1 presents the distribution of the respondents with respect to the municipality size, indicating that the variety in this dimension is adequately covered.

Table 1. Selection of respondents in municipalities of different sizes.

\begin{tabular}{cc}
\hline Municipality Size & Number of Respondents \\
\hline Smaller-sized $(<35,000$ inhabitants) & 10 \\
Mid-sized $(35,000-65,000$ inhabitants) & 11 \\
Larger-sized ( $>65,000$ inhabitants) & 11 \\
Unknown (no information provided) & 5 \\
\hline
\end{tabular}

\subsection{The Q-Sorting Task}

The selected respondents were interviewed with the help of an online programme, FlashQ. The selected respondents received an e-mail containing a URL to the interview questions. In the interview, the respondents first had to order the 39 statements (of the Q-sort) according to a quasi-normal distribution that ranged from completely agree $(+5)$ to completely disagree $(-5)$. The respondents were asked to order the statements based on the question: "To what extent do you agree or disagree with the following statements?" After ordering the statements, the respondents were asked for a motivation of the statements they agreed with most (+5) and disagreed with most (-5). These motivations were later used to interpret the perspectives.

During the last part of the interview, the respondents were asked to answer several additional questions, including their level of education, date of birth, gender, the municipality that he/she is working for, their job description, and the current open data policy of the municipality.

\subsection{Factor Analysis}

The 37 Q-sort responses were factor analyzed using centroid factor analysis, after which Varimax rotation was applied to achieve a simple structure. To execute the analysis, the software PQMethod version 2.35 was used [65]. Solutions with different numbers of factors extracted (1-7) were tested. Based on the criterion that at least two persons should significantly load on a factor to identify a shared perspective, the three-factor solution was considered optimal.

To compute the factor scores, we identified "factor exemplars", which are respondents/Q-sorts that load significantly on a particular factor, and can therefore be considered representative of the thought pattern in that factor. In total, 25 respondents were loaded solely on one factor, and three respondents were loaded on multiple factors. Twelve of the respondents did not load on any of the factors. Hence, the Q-sorts of 28 respondents (28 unique municipalities) were used to compute the factor scores. For each factor, we calculated the factor scores by computing a weighted sum score of the Q-sorts belonging to its factor exemplars (using the factor loadings as weights). We then recoded the resulting scores to match the forced distribution that was used in the Q-sorting task. Thus, the highest weighted factor score was recoded as +5 , the next two highest scores were recoded as +4 , and so on.

The recoded scores for each of the four factors are shown in Table 2 . In the next section, we use these scores to interpret each viewpoint. 
Table 2. Factor scores of the three extracted factors.

\begin{tabular}{|c|c|c|c|c|}
\hline \multirow{2}{*}{$\begin{array}{l}\text { Statement } \\
\text { Number }\end{array}$} & \multirow{2}{*}{ Statements } & \multicolumn{3}{|c|}{ Factor Scores } \\
\hline & & 1 & 2 & 3 \\
\hline 1 & Civilians need to be able to control what the municipality does in their name and interest. & 2 & 2 & 2 \\
\hline 2 & It is essential for municipalities to obtain feedback on their services. & -1 & 0 & 1 \\
\hline 3 & Data collected by municipalities is worth more when opened up. & 1 & 0 & 0 \\
\hline 4 & It is acceptable that municipal data can be used for espionage. & -2 & 5 & -5 \\
\hline 5 & I find it disturbing when municipal data is opened. & -5 & -2 & -4 \\
\hline 6 & It is important for a municipality to be transparent and open. & 4 & 3 & 4 \\
\hline 7 & $\begin{array}{l}\text { The applications (such as apps with information on air quality) that are made with open } \\
\text { data are going to change the world. }\end{array}$ & 1 & 1 & 0 \\
\hline 8 & The image of the municipality worsens due to the opening of data. & -4 & -4 & -3 \\
\hline 9 & The opening up of municipal data improves the democratic legitimacy. & 1 & 4 & 0 \\
\hline 10 & An open municipality is necessary in order for civilians to have a direct influence. & 1 & 2 & 0 \\
\hline 11 & It is important for the economy of a country that corporations have access to municipal data. & 0 & -1 & -1 \\
\hline 12 & It is acceptable that open data can be used for commercial purposes. & 0 & -3 & -1 \\
\hline 13 & $\begin{array}{l}\text { Data that municipal officials use on a daily basis can also be of importance for civilians } \\
\text { or businesses. }\end{array}$ & -1 & -2 & -2 \\
\hline 14 & Open municipal data can be a source for innovation. & 4 & 2 & 1 \\
\hline 15 & The opening up of municipal data needs to be an ordinary activity. & 5 & 1 & 1 \\
\hline 16 & $\begin{array}{l}\text { The usage of open municipal data asks for carefulness regarding handling the data of the } \\
\text { municipality (the owner of the data). }\end{array}$ & 1 & 3 & 5 \\
\hline 17 & $\begin{array}{l}\text { To benefit from all of the advantages of open municipal data, municipalities have } \\
\text { to collaborate. }\end{array}$ & 0 & 1 & 1 \\
\hline 18 & There needs to be more data awareness in municipalities. & 3 & 2 & 2 \\
\hline 19 & Municipalities need to speed up the opening of data. & 1 & 1 & -1 \\
\hline 20 & A municipality needs to have a different attitude to be called an open municipality. & 0 & 1 & 0 \\
\hline 21 & I am familiar with open data. & 3 & 1 & 0 \\
\hline 22 & The municipality is open to the civilians about what she does. & 0 & 1 & 3 \\
\hline 23 & The opening up of data is an unnecessary addition to my daily responsibilities. & -3 & -2 & -2 \\
\hline 24 & Stimulating the reuse of open municipal data is a task of the municipality. & -2 & 0 & -3 \\
\hline 25 & The municipality needs to open data against payment. & -4 & -4 & -4 \\
\hline 26 & I am afraid that wrong conclusions will be extracted from the open municipal data. & -3 & 0 & 1 \\
\hline 27 & The municipality itself has enough knowledge to open municipal data. & -2 & -2 & -3 \\
\hline 28 & Municipal data has to be opened in response to social problems, not just when asked for. & 2 & -1 & 1 \\
\hline 29 & The opening of data bears negative financial consequences for municipalities. & -3 & -3 & -1 \\
\hline 30 & $\begin{array}{l}\text { The priority for opening municipal data needs to align with the subjects in the High-Value Data } \\
\text { List (datasets about topics such as council information or monuments which might be valuable). }\end{array}$ & -2 & 0 & -2 \\
\hline 31 & Opening up municipal data cannot bear risks for the privacy of civilians. & 2 & 4 & 3 \\
\hline 32 & Open municipal data are a collective property of civilians. & 2 & -1 & 3 \\
\hline 33 & $\begin{array}{l}\text { Current legislation regarding the use of personal details and open data offers enough } \\
\text { protection for privacy. }\end{array}$ & 2 & -1 & -1 \\
\hline 34 & The privacy legislation forms an obstacle for the opening of data. & -1 & -1 & 2 \\
\hline 35 & The user needs to be able to assume that open data is veracious. & -1 & 5 & 4 \\
\hline 36 & Municipal data has to be opened up as complete and raw as possible. & 0 & -3 & 0 \\
\hline 37 & Open municipal data has to be accompanied by metadata (data that describes the data). & 3 & 0 & 2 \\
\hline 38 & As many datasets as possible have to be opened up. & 1 & 0 & -2 \\
\hline 39 & Datasets have to be clear; everyone needs to understand what the dataset states. & -1 & 3 & -1 \\
\hline
\end{tabular}




\section{Results: Motivation Perspectives on Opening up Municipality Data}

\subsection{Consistent Perspectives}

In this section, we discuss further the three main perspectives that we elicited. The three perspectives represent 28 out of the $37(75.7 \%)$ respondents, and therefore cover the interviewees' responses well, since only nine (24.3\%) respondents' responses could not be allocated to a perspective. The characteristics of each perspective are determined by the most extreme values. Based on these characteristics, we gave each perspective a label based on the typical phrases used by the respondents: (1) "the advocating municipality", (2) "the careful municipality", and (3) "the conservative municipality". Table 3 provides an overview of the main characteristics, which are discussed further below. The perspectives are ordered decreasingly by the number of respondents that they represent.

Table 3. Selection of respondents in municipalities of different size.

\begin{tabular}{|c|c|c|c|}
\hline \multicolumn{4}{|c|}{ Consistent Perspectives } \\
\hline & $\begin{array}{c}\text { Perspective 1: The Advocating } \\
\text { Municipality (14 Respondents out of 28) }\end{array}$ & $\begin{array}{l}\text { Perspective 2: The Careful Municipality } \\
\text { (8 Respondents out of 28) }\end{array}$ & $\begin{array}{c}\text { Perspective 3: The Conservative } \\
\text { Municipality (6 Respondents out of } 28 \text { ) }\end{array}$ \\
\hline
\end{tabular}

In the following sub-sections, each of the three perspectives is explained. When referring to the statements of the Q-sort, we do so by using "(No. X)", where X stands for the statement number. When referring to a quote by an individual respondent, we do so by using "(PX)", where $\mathrm{X}$ refers to the study's participant number.

\subsubsection{Perspective 1: The Advocating Municipality}

Summary of statements adhered to in this motivation perspective: Opening up municipal data offers many benefits. I do not have any problems with opening up municipal data, and I do not find the opening of municipal data to be a useless addition to my work tasks. Opening up data should be done by default.

The respondents adhering to this perspective are mainly working for the large-sized and mid-sized municipalities. This perspective was shared by 14 out of the 28 respondents. Of those 14 respondents, six respondents worked for a large-sized municipality (P5, P12, P18, P26, P31, P34), four worked for a mid-sized municipality (P4, P6, P19, P32), and three worked for a small-sized municipality (P8, P17, and P37). One respondent adhering to this perspective did not indicate the municipality for which that he or she worked (P35).

The advocating municipality sees various benefits of open municipal data. Such data does not only bring political and social benefits by improving the image and reputation of the municipality (No. 8); economic benefits can also be attained using open municipal data. Moreover, the advocating municipality believes that many benefits can be attained for society through new innovations that can be developed using municipality data (No. 14). The advocating municipality also states that the municipality should be open and transparent (No. 6). Opening up municipal data can contribute to this.

Hence, advocating municipalities follow the trend of opening up data, and are strongly in favor of this. They also stated that they are familiar with open data themselves (No. 21), and that they do not have a problem with opening up data at all (No. 5). The additional work that the advocating municipalities need to conduct to open up data is not a problem (No. 23). The many benefits are more important than the little amount of extra work that needs to be done. The advocating municipality does not fear the drawing of incorrect conclusions from municipal data (No. 26). They state that 
municipality data will immediately be used well. Therefore, municipalities should facilitate that municipal data can be used for new applications. It was stated that "companies can create beautiful new applications using the data" (P19).

Advocating municipalities aim to motivate other municipalities to also open up their data. Since they clearly see the benefits of opening up municipal data, they would like to see other municipalities joining the open data movement. Their objectives including making opening up municipal data normal practice (No. 15), and opening up data by default. To attain these objectives, the respondents believe that more data-awareness should be created within the municipality (No. 18). Civil servants of the municipality should know the value of the data with which they work. Furthermore, they should be aware of the possibilities of other people using the data. Only when other civil servants also have the same believes and motivations concerning the opening of municipal data can this be done extensively. Eventually, respondents adhering to this advocating perspective would love to see that the municipality is going to open up data when there are signals that this could potentially be useful for society to have that particular type of data (No. 28). They want the municipality to embrace its role as data and information provider, rather than making it necessary for inhabitants to request data and information.

The advocating municipality clearly sees the most important benefits that open municipal data can offer. Therefore, it is no problem to conduct the tasks that are necessary to share the data. The respondents want to see all of the municipalities opening up data.

\subsubsection{Perspective 2: The Careful Municipality}

Summary of statements adhered to in this motivation perspective: Opening up municipality data offers many benefits, yet the municipality should be careful when opening up data. Misuse of the data should be prevented.

The second perspective was shared by eight respondents, of whom two worked for a large-sized municipality (P2, P18), two worked for a mid-sized municipality (P13, P21), three worked for a small-sized municipality (P3, P11, P16), and one respondent did not indicate the municipality size (P22).

The careful municipality clearly sees the large benefits that opening up municipal data can lead to, and mainly acknowledges the political and social benefits. They state that sharing municipal data can lead to a higher democratic legitimacy (No. 9), since open municipal data allows inhabitants to investigate what the municipality does and hold the municipality accountable. Moreover, the careful municipality postulates that, "inhabitants of a modern society expect that it is transparent, accessible, and open" (P21). Therefore, by opening up municipal data, the respondents who adhere to this perspective believe that the image and reputation of the municipality will improve (No. 8). These benefits motivate careful municipalities to open up data.

The careful municipality indicates that opening up data brings along various new tasks regarding carefulness for the municipality (No. 16). The opened up data should be correct (No. 35); otherwise, the benefits of the data could be nullified by the consequences of sharing incorrect data. In addition, the careful municipality wants to ensure that inhabitants can easily understand the meaning of the data. This should prevent that new applications use incorrect data, or that users draw incorrect conclusions from the data. Therefore, the data that is opened up should be provided with metadata that clearly describes the dataset (No. 37). Moreover, datasets should be opened in such a way that they are very clear, and that citizens can easily understand them (No. 39). Careful municipalities also state that aggregated data are good enough to be opened up (No. 36). In this way, the municipal data are both opened up, and the municipalities meet the demands to become more open; at the same time, providing aggregated data avoids various risks related to the data provision.

Besides the risk that the data could be interpreted incorrectly, which the careful municipality wants to avoid, these municipalities also foresee other risks associated with opening up data. These risks should all be avoided as much as possible. The most important aspect is that "misuse should always be prevented", as stated by one of the respondents (P11). It is not acceptable for the careful municipality that 
municipal data is being used as a means for espionage (No. 4). Furthermore, the careful municipality is not in favor of using municipal data for commercial purposes (No. 12), and careful municipalities believe that that they are obliged to prevent privacy risks (No. 31).

In sum, the careful municipality does endorse the benefits of opening up municipal data, yet to realize these benefits, the municipality should avoid data misuse, and should work carefully with the data that is being opened up.

\subsubsection{Perspective 3: The Conservative Municipality}

Summary of statements adhered to in this motivation perspective: The municipality should be transparent and open, but it already is, to a large extent. Risks in opening up municipal data should be avoided. There are many obstacles that prevent opening up municipal data.

This perspective was shared by six respondents, including five from a small-sized municipality (P15, P16, P17, P20, P27), and one that did not provide information about the municipality size (P14).

For the conservative municipality, avoiding the failure of organizational processes is essential. Respondents who adhere to this perspective believe that some things should not change. The conservative municipality states that it is the task of the municipality to avoid unnecessary risks. Yet, by opening up municipal data, these risks cannot be avoided. This perspective is characterized by the importance of avoiding the risk of sharing incorrect data (No. 6) and by the strong carefulness that the municipality should adopt when working with the data (No. 15). The conservative municipality mainly wants to avoid the consequences of carelessness and negligence. Furthermore, this municipality indicates that the possibilities that open municipal data offers for espionage (No. 4) do not meet the obligation that the municipality has to serve the interests of its inhabitants (P17). Furthermore, the conservative municipality believes that stimulating the use of open data is not the task of the municipality (No. 24). This additional task would avoid that municipal employees can work on more crucial tasks, and is not good for the well-functioning of working processes of the municipality.

The conservative municipality does acknowledge that the municipality should be transparent and open (No. 6). However, the respondents adhering to this perspective believe that the municipality is already very open in involving its inhabitants (No. 22). There is no necessity to open up more municipal data, even though they do believe that opening up more data could lead to an even more transparent and open municipality. That is why they disagree with the statements that opening up data should be stimulated more (No. 19), and they disagree that as much data should be opened up as possible (No. 38). They rather prefer that the risks of opening up data are avoided.

Despite the risk-avoiding attitude of the conservative municipality, the respondents adhering to this perspective do indicate that they do not find it "annoying" if data are being opened up (No. 5). These municipalities mainly see a number of obstacles that make it impossible to open up municipal data. The most important obstacle probably has to do with this perspective being dominant among small-sized municipalities. The respondents state that the municipality simply does not possess sufficient digital knowledge or means to open up data itself (No. 27), which may be related to these municipalities being mainly small-sized. Hence, this is the reason for conservative municipalities to not give priority to opening up data, as stated by one of the participants (P15). Moreover, these municipalities state that the data protection legislation prevents much of the data from being opened up (No. 34). As such, the obstacles are not only present within the municipality itself, but are also imposed to the municipality by the national government.

In sum, the conservative municipality does acknowledge that open municipal data can lead to benefits. The many risks related to opening up data and number of obstacles to opening up data probably cause the conservative municipalities to not put too much effort in ensuring that municipal data is shared with the public. 


\subsection{Comparison between Perspectives}

The three perspectives reveal both similarities and differences (see Figure 1). The similarities can be found in the overlapping areas of the three circles of the figure, whereas the unique aspects of a perspective can be found in the areas of the circles that do not overlap with another area. The most important aspect that all of the respondents agree on is that residents should be able to check what the municipality does. The respondents who adhered to all three motivation perspectives agreed that inhabitants need to be able to monitor and control what a municipality is doing. By offering this possibility, they expect that citizens trust the municipality more. Furthermore, the respondents who adhered to each of the three perspectives saw multiple institutional barriers for opening up municipal data. For example, it was stated that more "data awareness" is needed within the municipality. Moreover, within each of the perspectives, it was emphasized that the municipality does not always have sufficient knowledge to open up its data. The conservative municipalities were especially clear about this. A final aspect that was shared among all the perspectives is that when data is provided, this should be done for free.

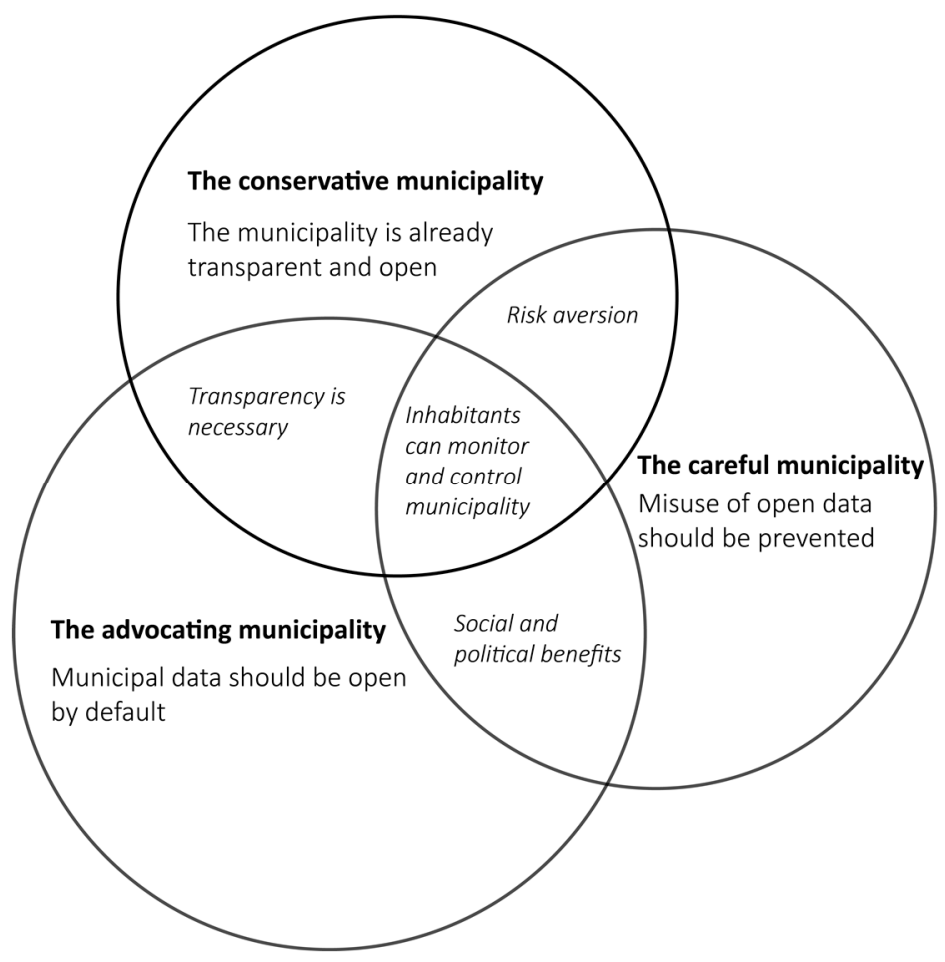

Figure 1. Graphical representation of differences and similarities between municipalities' motivation perspectives on opening up municipal data.

The similarity that can be found between the conservative municipality and the careful municipality is that they both want to avoid the risks that can arise whilst opening data. The conservative municipalities want to avoid this, because they do not believe that it is necessary for them to open up any data. The careful municipalities, on the other hand, want to prevent misuse, and therefore want to avoid risks.

One aspect that the conservative municipalities and the advocating municipalities have in common is that they believe that transparency and openness are necessary conditions for the municipalities to be able to execute their tasks. The conservative municipalities state that they are already open in all of their tasks, whereas the advocating municipalities believe they should work in an even more open way than they currently do. The advocating municipalities believe that everything should be done to open up data, whereas the conservative municipalities state that the opening of data is not necessary, since the municipality is already open and transparent. 
The advocating municipality and the careful municipality both recognize the possible social and political benefits that can emerge when data is opened. In both perspectives, it is stated that opening up municipal data leads to some image improvements for the municipality, as their reputation among municipality inhabitants may improve. Moreover, in both perspectives, the municipalities want to realize these benefits, and hence open up municipal data. The advocating municipalities and the careful municipalities both want to ensure that privacy risks do not arise when opening up municipal data. They also share the belief that the opened data might be used for espionage. The difference between these two perspectives is that the advocating municipalities want the opening of data to happen by default, so that as much data as possible is opened up, and as many of the open data benefits are achieved. The careful municipalities want to take things more slowly to prevent the data from being misused.

The most important topic on which the perspectives differ concerns the municipalities' position about what the role of the municipality is in opening up data. This includes the degree of responsibility of the municipality for the reuse of the data, as well as the level at which the municipality should avoid the risks of data use. Another topic of disagreement concerns the risks of opening up municipal data. Some respondents stated that the risks mainly concern the type of data that was used. In contrast, others stated that the risks mainly lie in the incorrect interpretation of the data. It is debatable whether it is the role of the municipality to ensure that data is not misinterpreted, or how this might be achieved.

\section{Recommendations for National Governments to Stimulate Opening up Municipality Data}

In this section, we discuss the influence of municipality size on motivation perspectives for opening up municipality data in comparison with the available literature in this area (Section 5.1). In addition, we relate our findings to recommendations for national governments on how to account for municipality size when developing future open data policies (Section 5.2).

\subsection{Comparison of Our Findings to the Literature}

The three motivation perspectives that were elicited in our study range on a scale from very much adhering to the open data movement (perspective 1) to barely adhering to the open data movement (perspective 3). Another perspective (perspective 2) was found to be in between these two more extreme perspectives. Our study showed that the third perspective, namely the conservative municipalities, were all small-sized municipalities, although there was one municipality adhering to this perspective that did not indicate its municipality size. Although our sample size is small, our findings suggest that large-sized and mid-sized municipalities are more likely to be motivated to open up their data compared to small-sized municipalities. However, three small-sized municipalities were also adhering to the first perspective for most motivated municipalities opening up their data (P8, P17, P37). Moreover, three small-sized municipalities were adhering to the second perspective (the careful municipalities); these were also somewhat motivated to open up their municipal data. So, out of the 11 identified small-sized municipalities, five adhered to the more conservative, third perspective showed that there is not a direct correlation between municipality size and motivations for opening up municipal data. On the other hand, several respondents who adhered to the third perspective of conservative municipalities did state that the size of the municipality influenced their motivation perspectives concerning the opening of municipal data. The lack of sufficient digital knowledge and means to open up data were mentioned as important reasons for not opening up municipal data, or for only doing so on a small scale. Thus, our findings do not support the statement "the smaller the municipality, the less motivated it is to open up its data", yet our findings do confirm the literature in the sense that the type and amount of governmental resources may influence municipalities' motivations to open up data or not, as mentioned as a possible explanation by Gill, et al. [17]. The large-sized and mid-sized municipalities do not mention problems with opening up data related to a lack of resources. A possible explanation for this is that large municipalities usually have more money and personnel to ensure that the necessary human resources, information and data resources and information technology (IT) resources are in place. 
Based on Musto et al. [66], Gill [16] refers to two size effects for opening up municipal data. First, he found that smaller-sized municipalities feel that their open data policies have smaller chances of success than those of larger-sized municipalities. A second size effect that Gill [16] referred to is that because of data jurisdiction, the data of smaller-sized municipalities is usually fragmented, and may not be easily interoperable, making it difficult for data users to use and compare data from more than one municipality. In our study, we did not find support for these two effects. The smaller-sized municipalities in our study do not refer to the limited chances of success if they would open up their data, and they do not refer to the size of the municipality as a factor influencing the success of their municipal open data initiative. In contrast, the smaller-sized municipalities that were involved in our study did acknowledge the potential benefits of opening up municipal data. For example, the smaller-sized municipalities did not state that their population and communities might be less interested in open data, although this was found to be a potentially influencing factor according to the literature [17]. Furthermore, in our study, the respondents did not refer to the difference in the type and usability of data being collected as a factor influencing their motivations to open up data or not, although the literature suggests that this may be an influencing factor [17]. In addition, when we asked the respondents for explanations of their motivations and perspectives, the fragmentation of municipality data and the lack of interoperability were not mentioned. This is an interesting finding for which we do not yet have an explanation. Besides, our respondents did not refer to the lack of usability of their data as a specific factor explaining their motivations.

According to our respondents, a much more important obstacle for opening up the data of conservative and mainly smaller-sized municipalities than the smaller chances of success or lack of data usability were insufficient internal resources and working processes that did not allow for opening up data. This may suggest a greater awareness of open data and open data practices by the municipalities in the Netherlands in comparison to studies in western Canada $[16,17,21]$, which could be linked to a number of factors, including governmental and NGO advocacy of open data, political, social, and economic influences, and the time between studies. Civil servants working for municipalities that adhere to the "conservative" perspective have to prioritize other activities, which leads them being unable to spend time on or invest effort in providing data to the public. In our sample of Dutch municipalities, the lack of provision of municipal data appeared to be not so much related to the lack of intrinsic motivations; instead, it was much more driven by extrinsic factors that hindered the opening of the data.

\subsection{Recommendations}

If national governments can identify which municipalities adhere to which motivation perspective, they can develop much more targeted open data policies that meet the requirements of the municipalities adhering to each perspective. Unfortunately, the confidentiality and sample size in our study do not allow for mapping municipal perspectives to certain geographical areas.

The advocating municipalities, the careful municipalities, and the conservative municipalities each require a different type and level of support. We developed the following recommendations for national governments aiming to stimulate open data sharing by municipalities for each of the three types of municipalities that were elicited in our study.

First, we recommend that national governments that are aiming to stimulate open data-sharing by advocating municipalities (perspective 1) mainly focus on intrinsic motivations. Our study shows that advocating municipalities are already strongly motivated to open up municipal data. They mainly see the benefits of opening up municipal data, and possible obstacles play a much smaller role in their view. Our findings suggest that advocating municipalities might benefit the most from meetings and events with other municipalities sharing the same perspective, so that they are kept motivated to open up municipal data over the long-term.

Second, we recommend that national governments that are aiming to stimulate open data sharing by careful municipalities (perspective 2) focus on data protection support and support for avoiding data 
misuse. Our study suggests that careful municipalities might become more motivated to open up their data if sufficient human support and guidelines are provided regarding how data misuse can be avoided.

Third, we recommend that national governments that are aiming to stimulate open data sharing by conservative municipalities (perspective 3) not only focus on internal conditions that facilitate the opening of municipal data, but also on external conditions. In the Netherlands, internal motivations are often discussed at the multiplicity of the events that are organized, aiming to stimulate municipalities and other governmental organizations to join the open data movement, yet external conditions have received less attention. One specific condition that we recommend national governments to focus on in their policies is to ensure that especially smaller-sized conservative municipalities are supported through an open data infrastructure, human resources, and appropriate IT resources. These municipalities do not have these resources themselves, and need to be supported.

\section{Conclusions}

The objective of this paper is to reveal how municipality size influences municipalities' motivation perspectives on opening up municipality data. Using Q-methodology and applying it to 37 municipalities in the Netherlands, we elicited the motivation perspectives of three main groups of municipalities on opening up data as follows: (1) the advocating municipality, (2) the careful municipality, and (3) the conservative municipality. We found that the first perspective is mainly present among large-sized municipalities (more than 65,000 inhabitants), but a few small-sized municipalities (less than 35,000 inhabitants) also adhered to this perspective. The second perspective could be found among municipalities of all sizes (small, medium, and large). In our study, we only found the third perspective for smaller-sized municipalities, and for one municipality that did not provide information about its size. We found that all of the municipalities considered accountability important for the possibility of residents to inspect and supervise municipality decisions. Small-sized conservative municipalities indicated that they lacked the human, technical, and other resources to open up data.

If national governments can identify which municipalities adhere to which motivation perspective, they can then develop much more targeted open data policies that meet the requirements of the municipalities that adhere to each perspective. We formulated three recommendations for national governments aiming to stimulate the sharing of municipal data with the public: (1) support advocating municipalities (perspective 1) by focusing on intrinsic motivations, (2) support careful municipalities (perspective 2) by focusing on data protection support and support for avoiding data misuse, and (3) support conservative municipalities through an open data infrastructure, human resources, and appropriate IT resources, since they often do not have these resources themselves (mainly external conditions).

A limitation of this study is that we did not ask the municipalities themselves whether they believe that municipality size influences their motivations for opening up data or not. Information about the influence of municipality size was derived from other information provided by the respondents. Another limitation is that we focused on the motivation perspectives of individual respondents working for a certain municipality, assuming that these perspectives can be translated one-to-one to the motivation perspectives of entire municipalities. However, we asked respondents to answer the interview questions from the perspective of the municipality for which they worked. We recommend future research to conduct in-depth interviews or a questionnaire including questions about the available municipal resources and digital means for opening up municipality data, so that these can be compared between different-sized municipalities. Moreover, we recommend future studies to investigate whether our findings hold when a larger set of municipalities is involved, since our study involved 37 responses in total. With a larger and more probabilistic sample, the relationship between municipality size and perspective membership may be tested statistically. In addition, possible confounding factors should also be included in such an analysis, such as personal characteristics of respondents. By controlling for these factors, the unique contribution of municipality size on viewpoint membership may be assessed. 
Author Contributions: Conceptualization, A.Z., C.V., M.K. and M.G.; Methodology, C.V. and M.K.; Validation, C.V. and M.G.; Formal Analysis, A.Z., C.V. and M.K.; Investigation, C.V.; Data Curation, C.V. and M.K.; Writing-Original Draft Preparation, A.Z.; Writing-Review \& Editing, A.Z.; Visualization, C.V. and M.K.; Supervision, A.Z. and M.K.

Funding: This research received no external funding.

Acknowledgments: The authors would like to thank the interviewees for participating in this study.

Conflicts of Interest: The funders had no role in the design of the study; in the collection, analyses, or interpretation of data; in the writing of the manuscript, and in the decision to publish the results.

\section{Appendix A}

This attachment contains the complete concourse that we created. The concourse reflects what is said about a certain topic using a large variety of sources. In order to create this concourse, we looked at scientific literature, popular literature, policy documents, and news items.

Table A1. Concourse derived for this study (including sources).

\begin{tabular}{|c|c|c|c|}
\hline \multicolumn{4}{|c|}{ Consistent Perspectives } \\
\hline & Statement \# & Statements (Our Translations for Dutch Sources) & Source \\
\hline \multirow{24}{*}{ 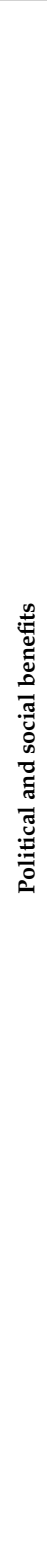 } & 1 & $\begin{array}{l}\text { By opening up data, external parties can look for smart } \\
\text { solutions to complex problems. }\end{array}$ & Sangen [67] \\
\hline & 2 & $\begin{array}{l}\text { By starting a collaboration in which various parties work } \\
\text { with open data, new insights can be obtained. }\end{array}$ & Sangen [67] \\
\hline & 3 & $\begin{array}{l}\text { Inhabitants should be able to follow what the government } \\
\text { does in their name and their interest. }\end{array}$ & $\begin{array}{l}\text { Tweede Kamer der } \\
\text { Staten-Generaal [42] }\end{array}$ \\
\hline & 4 & $\begin{array}{l}\text { By opening up data, you become a government that can be } \\
\text { monitored and checked. }\end{array}$ & Lemmens [53] \\
\hline & 5 & By opening up data, efficiency gains can be attained. & Lemmens [53] \\
\hline & 6 & $\begin{array}{l}\text { Open data allows inhabitants to have a more open and more } \\
\text { intelligent conversation with the government. }\end{array}$ & Lemmens [53] \\
\hline & 7 & $\begin{array}{l}\text { By opening up data, inhabitants are enabled to find ways to } \\
\text { analyze this and do something useful with it. }\end{array}$ & De Volkskrant [68] \\
\hline & 8 & $\begin{array}{l}\text { Governments can improve their service level by obtaining } \\
\text { feedback on their services. }\end{array}$ & Cohen $[60]$ \\
\hline & 9 & $\begin{array}{l}\text { It is the government's task to bring more objectivity to the } \\
\text { public discourse by offering the possibility of accessing the data. }\end{array}$ & Binnenlands Bestuur [58] \\
\hline & 10 & $\begin{array}{l}\text { Offering open data automatically bridges the distance } \\
\text { between the government and its inhabitants. }\end{array}$ & Boers and Kramer [69] \\
\hline & 11 & Governmental data is worth more when it is open. & Kroes [44] \\
\hline & 12 & The government should be open and transparent. & $\begin{array}{l}\text { Ministerie van Justitie } \\
\text { en Veiligheid [70] }\end{array}$ \\
\hline & 13 & It is acceptable that open data is being used for espionage. & $\begin{array}{l}\text { Ministerie van Justitie } \\
\text { en Veiligheid [50] }\end{array}$ \\
\hline & 14 & Managers suffer from open data. & $\begin{array}{l}\text { Ministerie van Justitie } \\
\text { en Veiligheid [50] }\end{array}$ \\
\hline & 15 & It is important for the municipality to be transparent and open. & $\begin{array}{l}\text { Ministerie van Justitie } \\
\text { en Veiligheid [50] }\end{array}$ \\
\hline & 16 & $\begin{array}{l}\text { Municipal datasets should be made available, because this is } \\
\text { the right thing to do. }\end{array}$ & $\begin{array}{l}\text { Ministerie van Justitie } \\
\text { en Veiligheid [50] }\end{array}$ \\
\hline & 17 & Open data is not going to change the world. & $\begin{array}{l}\text { Ministerie van Justitie } \\
\text { en Veiligheid [50] }\end{array}$ \\
\hline & 18 & Opening up data is going to counteract fraud. & Katan [71] \\
\hline & 19 & The image of the data provider improves by opening up data. & Welle Donker, et al. [72] \\
\hline & 20 & Opening up data stimulates democratic legitimacy. & Plasterk [41] \\
\hline & 21 & $\begin{array}{l}\text { An open government at the local level is an essential } \\
\text { condition for direct influence from inhabitants. }\end{array}$ & $\begin{array}{c}\text { Burgerpanel [48], } \\
\text { Ministerie van } \\
\text { Binnenlandse Zaken } \\
\text { en Koninkrijksrelaties [49] }\end{array}$ \\
\hline & 22 & $\begin{array}{l}\text { Managers and the civil servants of municipalities need to } \\
\text { govern and steer to realize transparency. }\end{array}$ & $\begin{array}{l}\text { Maatschappelijke } \\
\text { Coalitie voor een } \\
\text { Open Overheid [73] }\end{array}$ \\
\hline & 23 & It is important that the government becomes more open. & Burgerpanel [48] \\
\hline & 24 & The open government should be two-directional. & Burgerpanel [48] \\
\hline
\end{tabular}


Table A1. Cont.

\begin{tabular}{|c|c|c|c|}
\hline \multicolumn{4}{|c|}{ Consistent Perspectives } \\
\hline & Statement \# & Statements (Our Translations for Dutch Sources) & Source \\
\hline \multirow{9}{*}{ 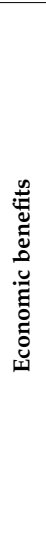 } & 25 & Open government data can lead to economic gains. & Giebels [43] \\
\hline & 26 & $\begin{array}{l}\text { The government has a treasure of data that entrepreneurs } \\
\text { can use. }\end{array}$ & Giebels [43] \\
\hline & 27 & Data is the new gold. & RTL Nieuws [74] \\
\hline & 28 & Government data can be used for innovations. & Ebbers [46] \\
\hline & 29 & $\begin{array}{l}\text { Access to government data for external parties is essential } \\
\text { for the economy. }\end{array}$ & Herbold [45] \\
\hline & 30 & $\begin{array}{l}\text { Structural economic development requires collaboration } \\
\text { between inhabitants, companies, and the municipality. }\end{array}$ & $\begin{array}{l}\text { van Veenstra, } \\
\text { van den Broek and } \\
\text { van der Plas [54] }\end{array}$ \\
\hline & 31 & $\begin{array}{l}\text { I find it acceptable that open data is being used for } \\
\text { commercial purposes. }\end{array}$ & $\begin{array}{l}\text { Ministerie van Justitie } \\
\text { en Veiligheid [50] }\end{array}$ \\
\hline & 32 & Open data is a source of inspiration for third parties. & Pronk [47] \\
\hline & 33 & $\begin{array}{l}\text { The data that civil servants work with is also meaningful to } \\
\text { inhabitants or companies. }\end{array}$ & Pronk [47] \\
\hline \multirow{17}{*}{ 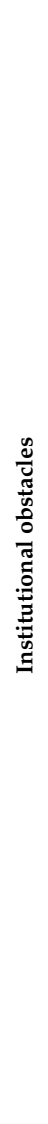 } & 34 & Opening up data should be part of the working processes. & Lemmens [53] \\
\hline & 35 & $\begin{array}{l}\text { Civil servants of municipalities should be prepared to } \\
\text { share data. }\end{array}$ & $\begin{array}{l}\text { Janssen, Charalabidis } \\
\text { and Zuiderwijk [40] }\end{array}$ \\
\hline & 36 & The cabinet should facilitate the "open by default" approach. & Hartholt [75] \\
\hline & 37 & $\begin{array}{l}\text { The government should take more initiative in actively and } \\
\text { digitally opening up the data that it possesses. }\end{array}$ & Blankena [76] \\
\hline & 38 & $\begin{array}{l}\text { Disclosing government data is not part of the primary } \\
\text { working processes of the municipality. }\end{array}$ & Blankena [76] \\
\hline & 39 & Making available open data should be an ordinary activity. & $\begin{array}{l}\text { Ministerie van Justitie } \\
\text { en Veiligheid [50] }\end{array}$ \\
\hline & 40 & $\begin{array}{l}\text { The pace at which more and more open data becomes } \\
\text { available to the public should be increased. }\end{array}$ & $\begin{array}{l}\text { Ministerie van Justitie } \\
\text { en Veiligheid [50] }\end{array}$ \\
\hline & 41 & $\begin{array}{l}\text { The use of open data requires extreme carefulness by the } \\
\text { data owner. }\end{array}$ & Pronk [47] \\
\hline & 42 & $\begin{array}{l}\text { Municipalities should collaborate to completely exploit the } \\
\text { benefits of open data. }\end{array}$ & Pronk [47] \\
\hline & 43 & More data awareness should be created within the organization. & van Gameren [51] \\
\hline & 44 & $\begin{array}{l}\text { Governmental organizations in the Netherlands need better } \\
\text { insight into which parts of society can profit from open data. }\end{array}$ & van der Steen [77] \\
\hline & 45 & $\begin{array}{l}\text { Openness is not just about opening up government data. } \\
\text { Openness is about a reasonable interaction between the } \\
\text { inhabitants and the government. }\end{array}$ & $\begin{array}{c}\text { Ministerie van } \\
\text { Binnenlandse Zaken } \\
\text { en Koninkrijksrelaties [49] }\end{array}$ \\
\hline & 46 & The government should speed up the provision of open data. & $\begin{array}{l}\text { Maatschappelijke } \\
\text { Coalitie voor een } \\
\text { Open Overheid [73] }\end{array}$ \\
\hline & 47 & $\begin{array}{l}\text { The government should become more open using } \\
\text { technological developments. }\end{array}$ & Burgerpanel [48] \\
\hline & 48 & $\begin{array}{l}\text { An open government is not just a matter of technology, but also } \\
\text { a matter of the attitude and behaviour of the government. }\end{array}$ & Burgerpanel [48] \\
\hline & 50 & There is openness within the municipality. & Burgerpanel [48] \\
\hline & 51 & $\begin{array}{l}\text { The opening up of data is an unnecessary addition to my } \\
\text { daily responsibilities. }\end{array}$ & $\begin{array}{l}\text { Agrawal, Kettinger } \\
\text { and Zhang [52] }\end{array}$ \\
\hline \multirow{8}{*}{ 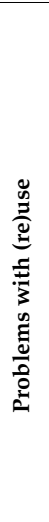 } & 52 & $\begin{array}{l}\text { Stimulating the reuse of open municipal data is a task of } \\
\text { the government. }\end{array}$ & Lemmens [53] \\
\hline & 53 & Only data that can easily be reused should be opened up. & Lemmens [53] \\
\hline & 54 & Only data that is fun to reuse should be opened up. & Lemmens [53] \\
\hline & 55 & I am afraid that the data will be used in the wrong way. & Cohen [60] \\
\hline & 56 & $\begin{array}{l}\text { I am afraid that wrong conclusions will be extracted from } \\
\text { the open data. }\end{array}$ & Cohen [60] \\
\hline & 57 & $\begin{array}{l}\text { Municipalities should stimulate the use of open data with } \\
\text { the help of, for example, hackathons. }\end{array}$ & $\begin{array}{l}\text { van Veenstra, } \\
\text { van den Broek and } \\
\text { van der Plas [54] }\end{array}$ \\
\hline & 58 & $\begin{array}{l}\text { Users of open data should have the ability to go to the } \\
\text { municipality with questions and remarks regarding the } \\
\text { open data. }\end{array}$ & Boers and Kramer [69] \\
\hline & 59 & The opening up of data should be driven by demand. & $\begin{array}{l}\text { Ministerie van Justitie } \\
\text { en Veiligheid [50] }\end{array}$ \\
\hline
\end{tabular}


Table A1. Cont.

\begin{tabular}{|c|c|c|c|}
\hline \multicolumn{4}{|c|}{ Consistent Perspectives } \\
\hline & Statement \# & Statements (Our Translations for Dutch Sources) & Source \\
\hline & 60 & $\begin{array}{l}\text { The responsibility for the wrong usage of open data lies } \\
\text { with the user. }\end{array}$ & $\begin{array}{l}\text { Ministerie van Justitie } \\
\text { en Veiligheid [50] }\end{array}$ \\
\hline & 61 & The provision of information should be done centrally. & Burgerpanel [48] \\
\hline & 62 & The government needs to open data against payment. & Ebbers [46]) \\
\hline & 63 & $\begin{array}{l}\text { The opening of data bears negative financial consequences } \\
\text { for governments. }\end{array}$ & Kamp [56] \\
\hline & 64 & I have enough knowledge about the use of open data. & Hartholt [57] \\
\hline & 65 & $\begin{array}{l}\text { The municipality itself has enough knowledge to open } \\
\text { municipal data. }\end{array}$ & Hartholt [57] \\
\hline & 66 & $\begin{array}{l}\text { The best way to open up data is by doing this driven } \\
\text { by problems. }\end{array}$ & van der Steen [77] \\
\hline & 67 & $\begin{array}{l}\text { The financial structure for data collection should be altered } \\
\text { in order to offer open data. }\end{array}$ & Kamp [56] \\
\hline & 68 & The benefits of open data are higher than the costs. & $\begin{array}{l}\text { Welle Donker, } \\
\text { van Loenen and } \\
\text { Korthals Altes [72] }\end{array}$ \\
\hline & 69 & $\begin{array}{l}\text { The priority for opening municipal data needs to align with the } \\
\text { subjects in the High-Value Data List (datasets about topics such } \\
\text { as council information or monuments that might be valuable). }\end{array}$ & de Groot [55] \\
\hline & 70 & $\begin{array}{l}\text { The government should actively inform people about the } \\
\text { information that is already open. }\end{array}$ & Burgerpanel [48] \\
\hline \multirow{19}{*}{ 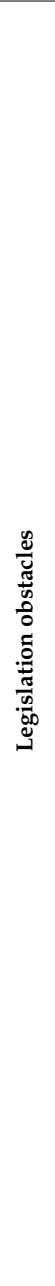 } & 71 & Only relatively safe data should be opened up. & $\begin{array}{l}\text { Janssen, Charalabidis } \\
\text { and Zuiderwijk [40] }\end{array}$ \\
\hline & 72 & Certain data should not be allowed to be opened up. & $\begin{array}{l}\text { Janssen, Charalabidis } \\
\text { and Zuiderwijk [40] }\end{array}$ \\
\hline & 73 & $\begin{array}{l}\text { The benefits and disadvantages of the reuse of } \\
\text { privacy-sensitive data should be compared carefully. }\end{array}$ & Herbold [45] \\
\hline & 74 & Government information is the possession of inhabitants. & Cohen [60] \\
\hline & 75 & $\begin{array}{l}\text { The government should become more aware about the risks } \\
\text { of opening data. }\end{array}$ & Binnenlands Bestuur [58] \\
\hline & 76 & $\begin{array}{l}\text { Open data should be protected in the same way as data that } \\
\text { is not made public. }\end{array}$ & Binnenlands Bestuur [58] \\
\hline & 77 & $\begin{array}{l}\text { All public data should be freely accessible, except when } \\
\text { there are pressing reasons not to do so. }\end{array}$ & van Eck [62] \\
\hline & 78 & $\begin{array}{l}\text { Whilst opening up data, careful considerations should take } \\
\text { place as to whether reuse of the data leads to new risks for } \\
\text { fundamental values and privacy. }\end{array}$ & $\begin{array}{l}\text { Ministerie van Justitie } \\
\text { en Veiligheid [59] }\end{array}$ \\
\hline & 79 & $\begin{array}{l}\text { A choice needs to be made between privacy on the one } \\
\text { hand, privacy and open data on the other. }\end{array}$ & $\begin{array}{l}\text { Ministerie van Justitie } \\
\text { en Veiligheid [50] }\end{array}$ \\
\hline & 80 & $\begin{array}{l}\text { Current legislation regarding the use of personal details and } \\
\text { open data offers enough protection for privacy. }\end{array}$ & $\begin{array}{l}\text { Ministerie van Justitie } \\
\text { en Veiligheid [50] }\end{array}$ \\
\hline & 81 & $\begin{array}{l}\text { The privacy legislation forms an obstacle for the opening } \\
\text { of data. }\end{array}$ & Kamp [56] \\
\hline & 82 & It should never be possible to trace a person by the open data. & Pronk [47] \\
\hline & 83 & Openness cannot induce safety risks for individuals. & Pronk [47] \\
\hline & 84 & Information is owned by the civilians, not by the government. & $\begin{array}{l}\text { Ministerie van Justitie } \\
\text { en Veiligheid [61] }\end{array}$ \\
\hline & 85 & $\begin{array}{l}\text { The constitutional right to privacy must also apply } \\
\text { unequivocally in the digital domain. }\end{array}$ & $\begin{array}{l}\text { Maatschappelijke } \\
\text { Coalitie voor een } \\
\text { Open Overheid [73] }\end{array}$ \\
\hline & 86 & $\begin{array}{l}\text { Access of the government in the private atmosphere should } \\
\text { be accompanied with at least the same guarantees as in the } \\
\text { physical world. }\end{array}$ & $\begin{array}{l}\text { Maatschappelijke } \\
\text { Coalitie voor een } \\
\text { Open Overheid [73] }\end{array}$ \\
\hline & 87 & Not all information should become public. & Burgerpanel [48] \\
\hline & 88 & $\begin{array}{l}\text { A careful distinction needs to be made between whether or } \\
\text { not data is public. }\end{array}$ & Burgerpanel [48] \\
\hline & 89 & $\begin{array}{l}\text { On a nation level, legislation should be established instead } \\
\text { of on a local level. }\end{array}$ & Burgerpanel [48] \\
\hline
\end{tabular}


Table A1. Cont.

\begin{tabular}{|c|c|c|c|}
\hline \multicolumn{4}{|c|}{ Consistent Perspectives } \\
\hline & Statement \# & Statements (Our Translations for Dutch Sources) & Source \\
\hline \multirow{14}{*}{ 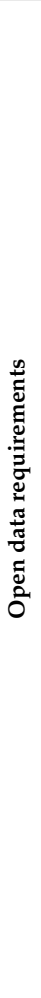 } & 90 & Open data should be trustworthy. & $\begin{array}{l}\text { Janssen, Charalabidis } \\
\text { and Zuiderwijk [40] }\end{array}$ \\
\hline & 91 & $\begin{array}{l}\text { The user needs to be able to assume that open data is } \\
\text { veracious. }\end{array}$ & $\begin{array}{l}\text { Janssen, Charalabidis } \\
\text { and Zuiderwijk [40] }\end{array}$ \\
\hline & 92 & $\begin{array}{l}\text { In the government policy, too little money is spend toward } \\
\text { improving the quality of data. }\end{array}$ & Ebbers [46] \\
\hline & 93 & $\begin{array}{l}\text { Data should be opened up in such a way that it is } \\
\text { understandable. }\end{array}$ & Telegraaf.nl [63] \\
\hline & 94 & $\begin{array}{l}\text { The government should add a sort of manual when opening } \\
\text { a dataset. }\end{array}$ & van Eck [62] \\
\hline & 95 & $\begin{array}{l}\text { Open data should be accessible as much as possible } \\
\text { without registration. }\end{array}$ & $\begin{array}{l}\text { Ministerie van Justitie } \\
\text { en Veiligheid [59] }\end{array}$ \\
\hline & 96 & As many datasets as possible have to be opened up. & $\begin{array}{l}\text { Ministerie van Justitie } \\
\text { en Veiligheid [64] }\end{array}$ \\
\hline & 97 & $\begin{array}{l}\text { Municipal data has to be opened up as complete and raw } \\
\text { as possible. }\end{array}$ & $\begin{array}{l}\text { Ministerie van Justitie } \\
\text { en Veiligheid [64] }\end{array}$ \\
\hline & 98 & $\begin{array}{l}\text { Attention should be given to the quality of the use of } \\
\text { open data. }\end{array}$ & Plasterk [41] \\
\hline & 99 & $\begin{array}{l}\text { Data should be opened up in a way in which it can easily } \\
\text { be compared. }\end{array}$ & Telegraaf.nl [63] \\
\hline & 100 & Open data should become available in an open standard. & $\begin{array}{l}\text { Ministerie van Justitie } \\
\text { en Veiligheid [59] }\end{array}$ \\
\hline & 101 & $\begin{array}{l}\text { Open municipal data has to be accompanied by metadata } \\
\text { (data that describes the data). }\end{array}$ & $\begin{array}{l}\text { Ministerie van Justitie } \\
\text { en Veiligheid [59] }\end{array}$ \\
\hline & 102 & $\begin{array}{l}\text { Governments need to form a register with government } \\
\text { information for their own information management as well } \\
\text { as to make it easier for civilians to find information. }\end{array}$ & $\begin{array}{l}\text { Maatschappelijke } \\
\text { Coalitie voor een } \\
\text { Open Overheid [73] }\end{array}$ \\
\hline & 103 & $\begin{array}{l}\text { Information needs to be communicated in such a way that } \\
\text { all people can understand it. }\end{array}$ & Burgerpanel [48] \\
\hline
\end{tabular}

\section{Appendix B}

\section{Survey}

This attachment contains the survey that was spread across municipalities in the Netherlands. The survey was available through [website].

\section{Welcome}

Thank you for being willing to fill out this survey. This research is part of [anonymized]. The topic of this research is the different perspectives that officials of municipalities have on the opening of data. The perspectives will be constructed by giving you several statements. It is asked that you order those statements. We ask you to order the statements according to your position at the municipality and your opinion.

Answering the survey will take about 20 to $30 \mathrm{~min}$. The survey is completely anonymous. Your data will be handled carefully.

Thank you for your contribution in advance.

With kind regards,

Cécile Volten

If you have any questions you can contact me through email: [e-mail address] or phone: [phone number].

\section{Introduction}

Municipalities keep on taking on more tasks from the national government. This means that they also collect more and more data. On a national level, an open data policy was released. Open data 
are data that are public and accessible without any restrictions. Next to that, their format ensures easy computation by computers. Open data can encompass many subjects, such as the budget of the municipality, but also an overview of the trees in the city.

With this survey, research will be done regarding the attitudes that officials of ICT departments of different municipalities have toward open data. With the results of this research, a more thorough analysis can be made about how more data on a local level should be opened up.

First of all, you will be asked to order 39 statements to the extent you agree with them. After, you will be asked to give a short motivation for your answers. Lastly, several questions regarding your background will be asked. Your data will of course be handled carefully.

Please enlarge your screen and press the "Next... " button to start the survey.

\section{Part 1}

In a moment, 39 statements will be shown (see Table A2). Please read the statements carefully and divide them in three categories:

- $\quad$ statements you don't agree with;

- $\quad$ statements you are neutral about;

- $\quad$ statements you agree with.

The statements can be dragged into the desired category or you can press the keys 1, 2, or 3 (pay attention: you might need to turn of the Num Lock on your keyboard to use the keys 1, 2, or 3). You can change your preference afterwards. If you wish to reread this instruction, press "Help" in the bottom right corner of the screen. If you want to read the text from the instruction again, press the button "Back ..." in the bottom left corner.

Table A2. Statements.

\begin{tabular}{ll}
\hline 1 & Civilians need to be able to control what the municipality does in their name and interest. \\
\hline 2 & It is essential for municipalities to obtain feedback on their services. \\
\hline 4 & Data collected by municipalities is worth more when opened up. \\
\hline 5 & It is acceptable that municipal data can be used for espionage. \\
\hline 6 & It is important for a municipality to be transparent and open. \\
\hline 7 & $\begin{array}{l}\text { The applications (such as apps with information on air quality) that are made with open data are going to } \\
\text { change the world. }\end{array}$ \\
\hline 8 & The image of the municipality worsens due to the opening of data. \\
\hline 9 & The opening up of municipal data improves the democratic legitimacy. \\
\hline 10 & An open municipality is necessary in order for civilians to have direct influence. \\
\hline 11 & It is important for the economy of a country that corporations have access to municipal data. \\
\hline 12 & It is acceptable that open data can be used for commercial purposes. \\
\hline 13 & Data that municipal officials use on a daily basis can also be of importance for civilians or businesses. \\
\hline 14 & Open municipal data can be a source for innovation. \\
\hline 15 & The opening up of municipal data needs to be an ordinary activity. \\
\hline 16 & $\begin{array}{l}\text { The usage of open municipal data asks for carefulness with handling the data of the municipality (the owner } \\
\text { of the data). }\end{array}$ \\
\hline 17 & To benefit from all of the advantages of open municipal data, municipalities have to collaborate. \\
\hline 18 & There needs to be more data awareness in municipalities. \\
\hline 20 & Municipalities need to speed up the opening of data. \\
\hline 22 & I mun familiar with open data. \\
\hline
\end{tabular}


Table A2. Cont.

\begin{tabular}{ll}
\hline 23 & The opening up of data is an unnecessary addition to my daily responsibilities. \\
\hline 24 & Stimulating the reuse of open municipal data is a task of the municipality. \\
\hline 25 & The municipality needs to open data against payment. \\
\hline 26 & I am afraid that wrong conclusions will be extracted from the open municipal data. \\
\hline 27 & The municipality itself has enough knowledge to open municipal data. \\
\hline 29 & Municipal data has to be opened in response to social problems, not just when asked for. \\
\hline 30 & $\begin{array}{l}\text { The priority for opening municipal data needs to align with the subjects in the High-Value Data List (datasets } \\
\text { about topics such as council information or monuments that might be valuable). }\end{array}$ \\
\hline 31 & Opening up municipal data cannot bear risks for the privacy of civilians. \\
\hline 32 & Open municipal data are the collective property of civilians. \\
\hline 33 & Current legislation regarding the use of personal details and open data offers enough protection for privacy. \\
\hline 34 & The privacy legislation forms an obstacle for the opening of data. \\
\hline 35 & The user needs to be able to assume that open data is veracious. \\
\hline 36 & The municipal data that is opened up has to be as complete and raw as possible. \\
\hline 37 & Open municipal data has to be accompanied by metadata (data that describes the data). \\
\hline 38 & As many datasets as possible have to be opened up. \\
\hline 39 & Datasets have to be clear; everyone needs to understand what the dataset states. \\
\hline
\end{tabular}

Please take the statements from the category "Agree" and read them again. You can scroll through the statements by making use of the scrollbar. After doing that, select the statements that you agree with most, and put those on the right-hand side of the scorecard, underneath the " +5 ".

Next, please read the statements in the category "Disagree" once more. Select again the statements you disagree with the most, and put those on the left side of the scorecard, underneath the " -5 ".

Select after doing this, from the left statements, the statements that you agree or disagree with most. Those may be put underneath the " $+4 / 4$ ". Go on with doing this until you run out of statements in the categories "Agree" and "Disagree".

Lastly, reread the statements in the category "Neutral". Order the statements in the boxes that are left over in such a way that all of the statements are ordered from most disagree (left) to most agree (right).
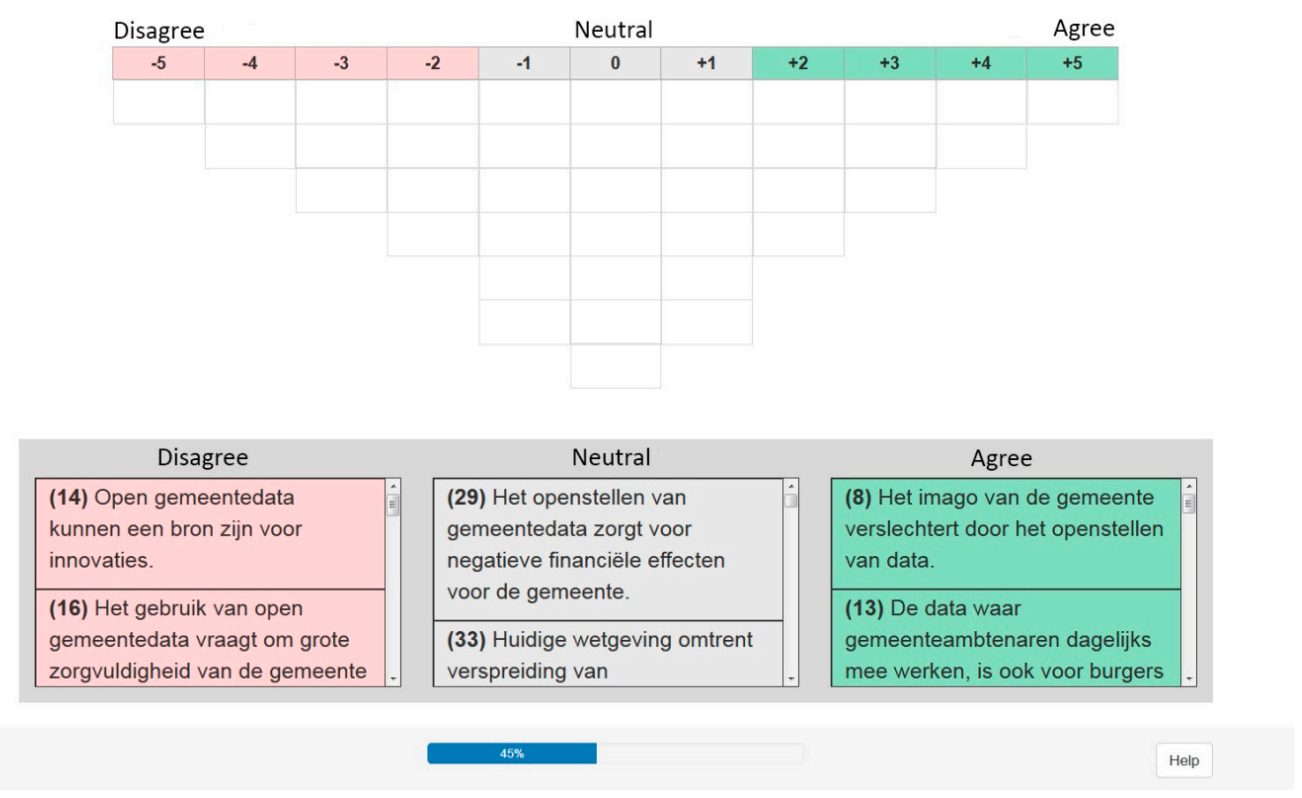

Figure A1. Sorting scheme online survey. 
As soon as all statements are put in a box a "Next ... " button will appear on the screen.

You have now put all of the statements in the scorecard. Please look at your distribution one more time, and if desired, please move and switch any statements. If you want to read certain statements once more as a whole, keep your mouse still on the box of that statement.

\section{Part 2}

Please explain in a couple of sentences why you agree or disagree with the statements underneath " $+5 "$ and " $-5 "$.

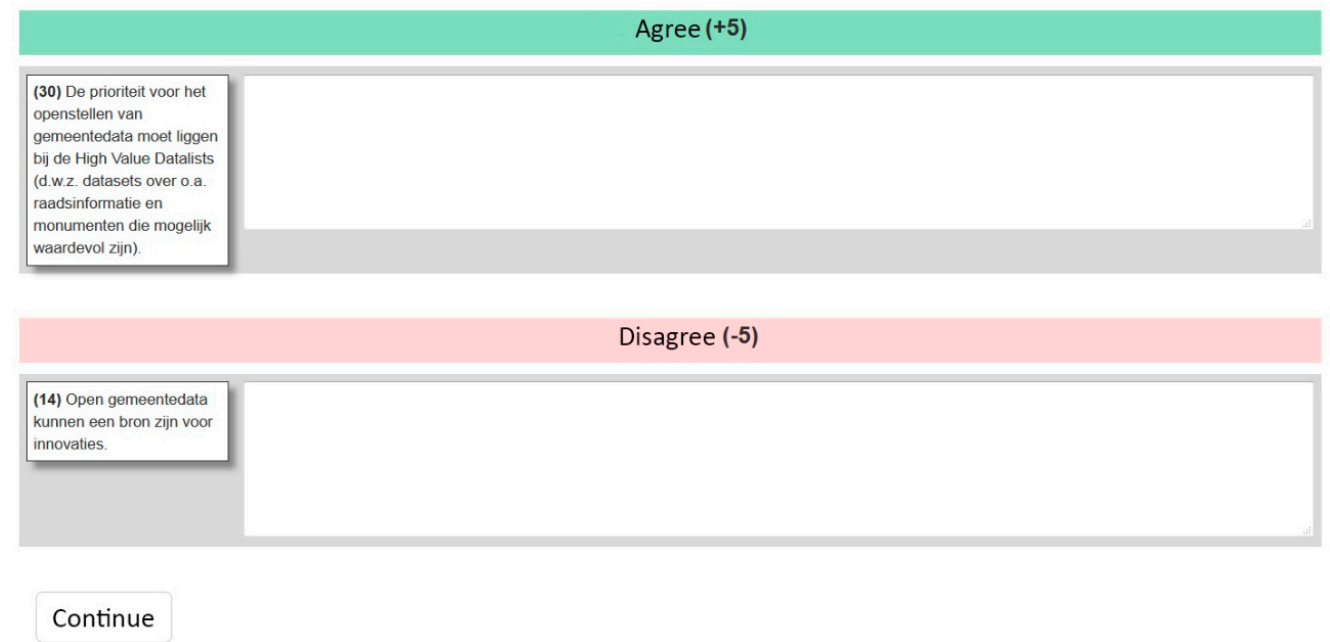

Figure A2. Survey question asking for explanation.

\section{Part 3}

Finally, some questions regarding your background information will be asked.

1. What is your birth date?

2. What is your gender? Male/Female/Other/Not applicable

3. What is the highest form of basic education you have had? Primary education/Lower vocational education/MAVO/MBO/HAVO/VWO/HBO/University

4. For what municipality are you working?

5. What is your position within this municipality?

6. How long have you been active in that position? $<1$ year $/ 1-2$ years $/ 3-5$ years $/ 5-10$ years $/>10$ years

7. Does the municipality where you work have an open data policy? Yes/No/Do not know

8. Is there a meeting about open data on a local level and with what regularity? Yes, weakly/Yes, monthly/No, never/Do not know/Different...

\section{Finally}

Thank you finishing the survey. Your contribution is of big value to this research. With the results of this research, an overview will be made of the perspectives that municipality officials have on open data.

1. Do you have any final remarks on this survey?

2. If you are interested in the results of this research, you can leave your e-mail address. It will only be used to send you the research report, not for other purposes. 


\section{References}

1. Porqueddu, E. Toward the open city: Design and research for emergent urban systems. Urban Des. Int. 2018, 1-13. [CrossRef]

2. Christiaanse, K.; Singler, J.; Rieniets, T. Open City: Designing Coexistence; Uitgeverij SUN: Amsterdam, The Netherlands, 2009.

3. Sennett, R. The Open City. Available online: http://www.richardsennett.com/documentdownload.axd? documentresourceid=2 (accessed on 7 August 2018).

4. Christiaanse, K. The open city and its enemies. In Open City: Designing Coexistence; Christiaanse, K., Singler, J., Rieniets, T., Eds.; Uitgeverij SUN: Amsterdam, The Netherlands, 2009; pp. 25-35.

5. Sennett, R. Building and Dwelling: Ethics for the City; Farrar, Straus and Giroux: New York, NY, USA, 2018.

6. Domingo, A.; Bellalta, B.; Palacin, M.; Oliver, M.; Almirall, E. Public open sensor data: Revolutionizing smart cities. IEEE Technol. Soc. Mag. 2013, 32, 50-56. [CrossRef]

7. Ojo, A.; Curry, E.; Zeleti, F.A. A tale of open data innovations in five smart cities. In Proceedings of the 48th Hawaii International Conference on System Sciences (HICSS), Kauai, HI, USA, 5-8 January 2015; IEEE: Honolulu, HI, USA, 2015; pp. 2326-2335.

8. Yadav, P.; Hasan, S.; Ojo, A.; Curry, E. The role of open data in driving sustainable mobility in nine smart cities. In Proceedings of the 25th European Conference on Information Systems, Guimarães, Portugal, 5-10 June 2017; pp. 1248-1263.

9. Granickas, K. Open City: Local Government E Open Data; European Public Sector Information Platform: Brussels, Belgium, 2015.

10. Abella, A.; Ortiz-De-Urbina-Criado, M.; De-Pablos-Heredero, C. A model for the analysis of data-driven innovation and value generation in smart cities' ecosystems. Cities 2017, 64, 47-53. [CrossRef]

11. Reggi, L.; Dawes, S. Open government data ecosystems: Linking transparency for innovation with transparency for participation and accountability. In Proceedings of the International Conference on Electronic Government and the Information Systems Perspective, Porto, Portugal, 5-8 September 2016; Volume 9820, pp. 74-86.

12. Kassen, M. A promising phenomenon of open data: A case study of the chicago open data project. Gov. Inf. Q. 2013, 30, 508-513. [CrossRef]

13. De Jager-de Lange, A. Nulmeting Open Data van Gemeenten. Available online: https:/ /www.vngrealisatie.nl/ sites/default/files/2017-10/Nulmeting\%20open\%20data\%20gemeenten\%20definitief\%20\%281\%29.pdf (accessed on 7 August 2018).

14. Lassinantti, J.; Bergvall-Kåreborn, B.; Ståhlbröst, A. Shaping local open data initiatives: Politics and implications. J. Theor. Appl. Electron. Commer. Res. 2014, 9, 17-33. [CrossRef]

15. Kleiman, F.; Janssen, M. Gaming to improve public policies by engaging local governments in open data policy-making. In Proceedings of the 19th Annual International Conference on Digital Government Research: Governance in the Data Age, Delft, The Netherlands, 30 May-1 June 2018.

16. Gill, M. Filtering Down: Open Data in Smaller Scaled Canadian Municipalities; University of British Columbia: Okanagan, BC, Canada, 2016.

17. Gill, M.; Corbett, J. Downscaling: Understanding the influence of open data initiatives in smaller and mid-sized cities in British Columbia, Canada. Can. Geogr. 2017, 61, 346-359. [CrossRef]

18. Conradie, P.; Choenni, S. On the barriers for local government releasing open data. Gov. Inf. Q. 2014, 31, S10-S17. [CrossRef]

19. Siebenlist, T.; Mainka, A. Culture of openness: The beginning of open government in municipalities in germany. In Proceedings of the 19th Annual International Conference on Digital Government Research: Governance in the Data Age, Delft, The Netherlands, 30 May-1 June 2018; p. 59.

20. Gómez, E.A.R. Perceptions about the concept and benefits of open government in local governments in spain. In Proceedings of the 10th International Conference on Theory and Practice of Electronic Governance, New Delhi, India, 7-9 March 2017; pp. 594-597.

21. Gill, M.; Corbett, J.; Sieber, R. Exploring open data perspectives from government providers in western canada. J. Urban Reg. Inf. Syst. Assoc. 2017, 28, 19-29.

22. Thorsby, J.; Stowers, G.; Wolslegel, K.; Tumbuan, E. Understanding the content and features of open data portals in american cities. Gov. Inf. Q. 2017, 34, 53-61. [CrossRef] 
23. Pinto, H.D.S.; Bernardini, F.; Viterbo, J. How cities categorize datasets in their open data portals: An exploratory analysis. In Proceedings of the 19th Annual International Conference on Digital Government Research: Governance in the Data Age, Delft, The Netherlands, 30 May-1 June 2018; p. 25.

24. Berends, J.; Carrara, W.; Vollers, H. Open Data in Cities 2. Available online: https:/ / www.europeandataportal.eu/ sites/default/files/edp_analytical_report_n6_-_open_data_in_cities_2_-_final-clean.pdf (accessed on 7 August 2018).

25. Amsterdam. Amsterdam Smart City. Available online: https://amsterdamsmartcity.com/projects/dataamsterdamnl (accessed on 7 August 2018).

26. Greater London Authority. Data for London. A City Data Strategy. Available online: https://files.datapress.com/ london/dataset/data-for-london-a-city-data-strategy/2016-05-19T15:39:34/London\%20City\%20Data\%20Strategy\% 20March\%202016.pdf (accessed on 7 August 2018).

27. Machado, V.; Mantini, G.; Viterbo, J.; Bernardini, F.; Barcellos, R. An instrument for evaluating open data portals: A case study in brazilian cities. In Proceedings of the 19th Annual International Conference on Digital Government Research: Governance in the Data Age, Delft, The Netherlands, 30 May-1 June 2018; p. 19.

28. Zuiderwijk, A.; Janssen, M.; Poulis, K.; Vandekaa, G. Open data for competitive advantage: Insights from open data use by companies. In Proceedings of the 16th Annual International Conference on Digital Government Research, Phoenix, AZ, USA, 27-30 May 2015.

29. Jeffers, P.I.; Muhanna, W.A.; Nault, B.R. Information technology and process performance: An empirical investigation of the interaction between it and non-it resources. Decis. Sci. 2008, 39, 703-735. [CrossRef]

30. Angelidou, M. Smart city policies: A spatial approach. Cities 2014, 41, S3-S11. [CrossRef]

31. Conradie, P.; Choenni, S. Exploring process barriers to release public sector information in local government. In Proceedings of the 6th International Conference on Theory and Practice of Electronic Governance, New York, NY, USA, 22-25 October 2012; pp. 5-13.

32. Brown, S.R. A primer on q methodology. Oper. Subj. 1993, 16, 91-138.

33. Webler, T.; Danielson, S.; Tuler, S. Using q Method to Reveal Social Perspectives in Environmental Research; Social and Environmental Research Institute: Greenfield, IN, USA, 2009.

34. Young, R.A.; Friesen, J.D.; Dillabough, J.-A.M. Personal constructions of parental influence relatied to career development. Can. J. Couns. Psychother./Revue Canadienne Counseling Psychothérapie 1991, 25, 183-190.

35. Sexton, D.; Snyder, P.; Wadsworth, D.; Jardine, A.; Ernest, J. Applying q methodology to investigations of subjective judgments of early intervention effectiveness. Top. Early Child. Spec. Educ. 1998, 18, 95-107. [CrossRef]

36. Gaebler-Uhing, C. Q-methodology: A systematic approach to assessing learners in palliative care education. J. Palliat. Med. 2003, 6, 438-442. [CrossRef] [PubMed]

37. Benlian, A.; Hilkert, D.; Hess, T. How open is this platform? The meaning and measurement of platform openness from the complementors' perspective. J. Inf. Technol. 2015, 30, 209-228. [CrossRef]

38. Van Exel, J.; de Graaf, G. Q Methodology: A Sneak Preview. Available online: https://www.researchgate.net/profile/ Gjalt_Graaf/publication/228574836_Q_Methodology_A_Sneak_Preview/links/02bfe50f946fc9978b000000.pdf (accessed on 20 July 2018).

39. Watts, S.; Stenner, P. Doing q methodology: Theory, method and interpretation. Qual. Res. Psychol. 2005, 2, 67-91. [CrossRef]

40. Janssen, M.; Charalabidis, Y.; Zuiderwijk, A. Benefits, adoption barriers and myths of open data and open government. Inf. Syst. Manag. 2012, 29, 258-268. [CrossRef]

41. Plasterk, R.H.A. Kamerbrief over Nationale Open Data Agenda 2016 (Noda). Available online: https: / /www.rijksoverheid.nl/documenten/kamerstukken/2015/11/30/kamerbrief-over-nationale36open-dataagenda-2016-noda (accessed on 12 May 2018).

42. Tweede Kamer der Staten-Generaal. Hackathon Met Overheidsdata in Tweede Kamer. Available online: https: //www.tweedekamer.nl/nieuws/kamernieuws/hackathon-met-overheidsdata-tweedekamer (accessed on 9 May 2018).

43. Giebels, R. Vvd: Maak Overheidsdata Voor Iedereen Beschikbaar. Available online: https://www.volkskrant. nl/economie/vvd-maak-overheidsdata-voor-iedereen-beschikbaar ba46b971/ (accessed on 9 May 2018).

44. Kroes, N. Opening Remarks, Press Conference on Open Data Strategy-Speech/11/872. Available online: http:/ / europa.eu/rapid/press-release_SPEECH-11-872_en.htm (accessed on 4 April 2018).

45. Herbold, M. Toegang tot overheidsdata essentieel voor economie. Het Financ. Dagblad, 21 March 2014. 
46. Ebbers, W. De Winst van Open Data. Available online: https://www.volkskrant.nl/nieuwsachtergrond/dewinst-van-open-data b435f578/ (accessed on 10 May 2018).

47. Pronk, P.; Data delen is een kracht. iBestuur, 2 November 2017. Available online: https://ibestuur.nl/ partner-minjenv / data-delen-is-een-kracht (accessed on 22 October 2018).

48. Burgerpanel. Advies Actieplan Open Overheid 2016-2017, June 2015.

49. Actieplan Open Overheid 2016-2017; Ministerie van Binnenlandse Zaken en Koninkrijksrelaties: The Hague, The Netherlands, 2015. Available online: https: / / www.rijksoverheid.nl/documenten/rapporten/2015/12/ 01/actieplan-open-overheid-2016-2017 (accessed on 23 October 2018).

50. Ministerie van Justitie en Veiligheid. Reuring!Café. Magazine Open Data, 7 November 2017.

51. Van Gameren, E. Het nieuwe goud. iBestuur, October 2017.

52. Agrawal, D.; Kettinger, W.; Zhang, C. The Openness Challenge: Why Some Cities Take it on and Others Don't. Available online: http:/ / aisel.aisnet.org/amcis2014/Posters/eGovernment/14 (accessed on 7 September 2018).

53. Lemmens, P. Interview met open data-specialist Paul Suijkerbuijk: Van open data naar open overheid. IP Vakblad Informatieprofessionals, 1 September 2013.

54. Van Veenstra, A.F.; van den Broek, T.; van der Plas, A. Hoe Realiseren We Economische Groei uit Open Data? Available online: https:/ / www.binnenlandsbestuur.nl/digitaal/opinie/ingezonden/economische-groeiuit-opendata.8509023.lynkx (accessed on 10 May 2018).

55. De Groot, M. Van nee tenzij naar ja tenzij. iBestuur, October 2017.

56. Kamp, H.G.J. Kamerbrief over Ontsluiting Handelsregister als Open Data. Available online: https://www. rijksoverheid.nl/documenten/kamerstukken/2016/07/04/kamerbrief-over-ontsluitinghandelsregister-alsopen-data (accessed on 12 May 2018).

57. Hartholt, S. Haal Meer Ict-Kennis in Huis. Available online: https:/ / www.binnenlandsbestuur.nl/digitaal/ achtergrond/achtergrond/haal-meer-ict-kennis-inhuis.9544197.lynkx (accessed on 10 May 2018).

58. Binnenlands Bestuur. Berners lee: Overheden Gaan Naïef om Met Open Data. Available online: https://www. binnenlandsbestuur.nl/ingovernment/nieuws/berners-lee-overheden-gaan-naief-ommet-open-data.9551886.lynkx (accessed on 10 May 2018).

59. Ministerie van Justitie en Veiligheid. De 8 Uitgangspunten voor Open Data. Available online: https://www. rijksoverheid.nl/documenten/publicaties/2017/09/21/de-8-uitgangspunten-voor-opendata (accessed on 10 May 2018).

60. Cohen, R. Schatkamer aan overheidsdata opengesteld. Het Financ. Dagblad, 5 November 2011.

61. Ministerie van Justitie en Veiligheid. Werkbezoek cbs. Magazine Open Data, 1 December 2017.

62. Van Eck, J.W. Open Data: Zorg voor een Goede Gebruiksaanwijzing. Available online: https: / /www.binnenlandsbestuur.nl/digitaal/opinie/ingezonden/open-data-zorg-voor-een-goedegebruiksaanwijzing. 9189394.lynkx (accessed on 10 May 2018).

63. Telegraaf.nl. Veel Data Vrij in te Zien, Behalve over Geld. Available online: https://www.telegraaf.nl/ nieuws /1036612/veel-data-vrij-in-te-zien-behalve-over-geld (accessed on 10 May 2018).

64. Ministerie van Justitie en Veiligheid. Beleid Open Data 2018. Available online: https://www.rijksoverheid. nl/documenten/publicaties/2018/04/20/beleid-2018-open-data (accessed on 10 May 2018).

65. Schmolk, P. Pq Methode Manual. Available online: http://schmolck.userweb.mwn.de/qmethod/pqmanual. htm (accessed on 28 July 2018).

66. Musto, C.; Basile, P.; Lops, P.; de Gemmis, M.; Semeraro, G. Introducing linked open data in graph-based recommender systems. Inf. Process. Manag. 2017, 53, 405-435. [CrossRef]

67. Sangen, M.V.D. Cbs en Postnl: Kennis Delen Tijdens Hackathon. Available online: https://www.cbs.nl/nl$\mathrm{nl} /$ corporate/2018/17/cbs-en-postnl-kennis-delen-tijdens-hackathon (accessed on 7 September 2018).

68. De Volkskrant. Obama Wil Meer Transparantie in Overheidsdata. Available online: https:/ www.volkskrant. nl/economie/obama-wil-meer-transparantie-in-overheidsdata bb1e40d7/ (accessed on 10 May 2018).

69. Boers, P.; Kramer, S. Open Overheidsdata: Ruwe Grondstof, Geen Oplospoeder. Available online: https:/ / www.binnenlandsbestuur.nl/digitaal/opinie/ingezonden/open-overheidsdata-ruwegrondstofgeen.8502202.lynkx (accessed on 10 May 2018).

70. Ministerie van Justitie en Veiligheid. Factsheet Open Data. Available online: https:/ / www.rijksoverheid.nl/ documenten/publicaties /2017/09/21/factsheet-open-data (accessed on 10 May 2018).

71. Katan, M. Het gevaar van open data. NRC, 24 December 2011. 
72. Welle Donker, F.M.; van Loenen, B.; Korthals Altes, W.K. Maatschappelijke Kosten-Batenanalyse Open Data; OTB-Onderzoek voor de Gebouwde Omgeving: Delft, The Netherlands, 2017.

73. Maatschappelijke Coalitie voor een Open Overheid. Manifest “Onze Overheid, Onze Informatie!". Available online: http:/ /open-overheid.nl/wp-content/uploads/2015/10/onze-overheid-onzeinformatie. pdf (accessed on 7 September 2018).

74. RTL Nieuws. Open Data, Wat is het en wat heb ik er aan? Available online: https://www.rtlnieuws.nl/ nieuws/binnenland/open-data-wat-het-en-wat-heb-ik-er-aan (accessed on 9 May 2018).

75. Hartholt, S. Gemeentelijke Open Data in een jaar Verdrievoudigd. Available online: https://www. binnenlandsbestuur.nl/digitaal/nieuws/gemeentelijke-open-data-in-een-jaar.9541076.lynkx (accessed on 10 May 2018).

76. Blankena, F. Weinig Schot in Open Data. Available online: https:/ /www.binnenlandsbestuur.nl/digitaal/ nieuws / geen-progressie-in-open-data.9430257.lynkx (accessed on 9 May 2018).

77. van der Steen, N. Het helpt overheden beter besturen. iBestuur, 29 October 2017.

(C) 2018 by the authors. Licensee MDPI, Basel, Switzerland. This article is an open access article distributed under the terms and conditions of the Creative Commons Attribution (CC BY) license (http:// creativecommons.org/licenses/by/4.0/). 